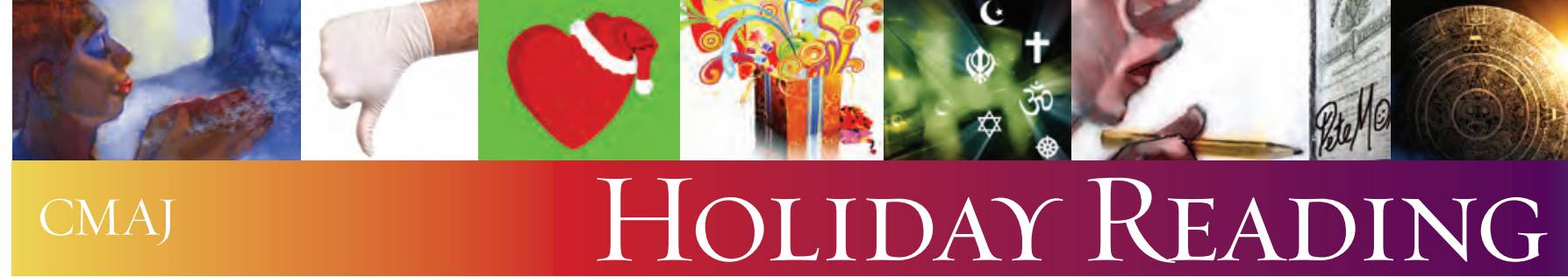

IN OTHER WORDS

\title{
The facts are the facts
}

\author{
Vinay Prasad MD
}

$\mathrm{N}$ o matter how much you know, you never know all the facts. Juggling facts pervades all parts of medicine. In particular, we seem to love the little contraindications.

"You can't take more than 2 litres off in a thoracentesis before you run the risk of re-expansion pulmonary edema."

"Are you sure you want to give her a dose of Imodium? Her C. diff results are not back yet."

"You should wait 72 hours after he stops linezolid before restarting his SSRI."

Facts come in all shapes and sizes. There are the big facts: this patient is having an ST elevation myocardial infarction. Then, there are the little facts: you order a stress test from nuclear medicine, but you call interventional radiology to schedule a lumbar puncture. Recently, a bright intern pointed out a little fact to me, which was big to him, just before I put on a sterile gown and gloves, in aseptic fashion, to place a central line.

"You need to wash your hands."

"I did."

"No, you didn't."

"What do you mean? I did as I entered the room."

"No, you have to do it again before you gown and glove."

"Who says?"

"Pronovost."

"What does he say?"

" "The use of gloves does not obviate the need for hand hygiene.' The checklist paper. New England Journal. 2006."

"How can that be? I'm about to put on sterile latex gloves, sterilely!"

"Hey, the facts are the facts."

Clearly bested, I went off to lick my wounds. I tried to get to the bottom of this fact. Sure enough, the supplementary appendix to the Pronovost paper included the line about handwashing, which cited a 1995 review on the subject. ${ }^{2}$ That paper indeed confirmed that infections had been reported, "even when gloves were worn." ${ }^{2}$ Four references were provided, numbers 156 to 159 . But, I didn't stop there. I wanted the facts.

I began with 156. "Removal of Nosocomial Pathogens from the Contaminated Glove" 3 - clearly a must-read. The paper showed that when volunteers put on nonsterile latex gloves, soaked their gloved hands in pathogen broth, and washed and dried their gloved hands with soap, chlorhexidine or alcohol hand sanitizer 5 times, redipping them in broth

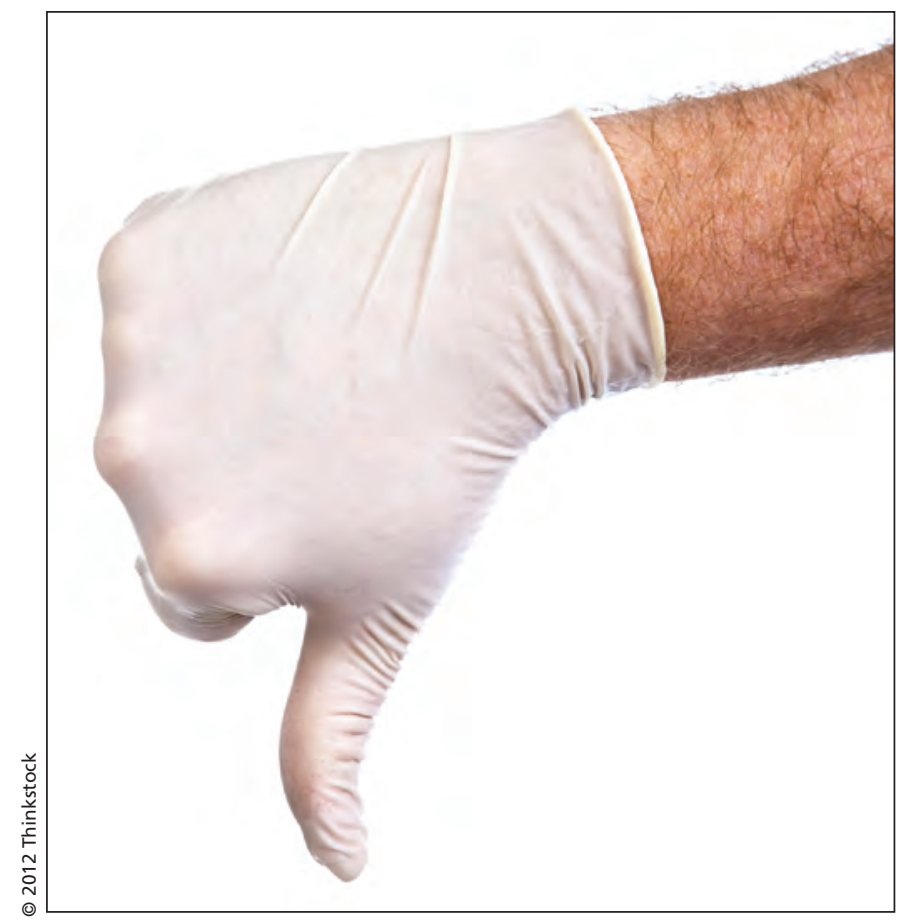

after each wash, then some fraction of the volunteers had pathogen cultured from their hands. Obviously, this study has tempered my enthusiasm for cleaning and collecting all gloves I have used, but for the point in question, I'm not sure this study says anything. Nonsterile gloves may break down with repeated chemical exposure and agitation.

Reference 157 had a more sobering title: "Risk of Human Immunodeficiency Virus (HIV-1) Infection among Laboratory Workers." ${ }^{4}$ The paper was a case report from the early years of HIV (1988) about a worker, with no known risk factors, found to have HIV. The presumptive source was virus-laden broth in a biosafety level 3 environment. Upon rigorous questioning, the worker stated he always double-gloved and was not sure when he was exposed. Again, I was unsure of how this citation made the case.

Surely 158 would provide the basis for the fact. With a title like "Latex and Vinyl Examination Gloves. Quality Control Procedures and Implications for Health Care Workers," ${ }^{5}$ how could it not? The paper began like a case on Law \& Order. In December 1987, in the wake of an outbreak of herpetic whit- 
low among nurses in a medical intensive care unit where all nurses wore gloves, the authors investigated the source of the scourge. Sure enough, they found that $11.1 \%$ of vinyl gloves they examined leaked water, whereas only $1.4 \%$ of the latex gloves did the same. The authors noted that no latex gloves passed herpes virus, but nevertheless recommended that glove manufacturers improve their standards. Although the case repulsed me, I still was unsure how the manufacturing practices of gloves 2 decades ago informed the current situation, in 2012. Oddly, I was reassured by the results for the latex gloves, which seemed to have passed, despite obviously medieval glove manufacturing standards in the late 1980s.

\section{Sometimes the facts are not the facts.}

A lot rested on the last paper, reference 159, "Examination Gloves as Barriers to Hand Contamination in Clinical Practice."' It was the most recent study, published in 1993, and appeared in the most prominent journal. It was a study of nonsterile gloves, used for 1 of 3 routine purposes: among respiratory therapists cleaning endotracheal tubes, nurses performing digital rectal examinations on patients with spinal cord injuries, and dentists in routine practice. Nearly $13 \%$ of gloved hands later showed contamination after routine use, though only 1 case involved a latex (as opposed to vinyl) glove. This was the closest I got to a relevant fact. Because a single nonsterile latex glove may have permitted contamination of a hand after dentistry or digital rectal examination 30 years ago, I should wash my hands before applying sterile latex gloves to place a central line in 2012, even though I washed my hands not 5 minutes before. To me, the facts were less than ironclad.
My long journey to learn the source of a fact reminded me of a conversation I had, with my friend the chemical engineer, while having bubble tea.

"I wonder why they float the way they do?" I asked.

"I can tell you this," he responded, "If you are curious about that question, you could take 2 semesters of fluid flow and mechanics. At the end of that time, I can't promise you'll have the answer, but I can promise that you won't care." I felt the same way at the end of my handwashing quest. By the time I had gotten to the bottom of it, I wished I had washed my hands.

The trouble with facts is that we tend to give them all the same weight when often they represent very different knowledge claims. Trainees, I fear, take all facts they are given at face value, handling each one with great care. But, sometimes the facts are not the facts, pearls are glass beads and depth of understanding is more important than pointing out the next quick fact.

\section{References}

1. Pronovost P, Needham D, Berenholtz S, et al. An intervention to decrease catheterrelated bloodstream infections in the ICU. N Engl J Med 2006;355:2725-32.

2. Larson EL. APIC guideline for handwashing and hand antisepsis in health care settings. Am J Infect Control 1995;23:251-69.

3. Doebbeling BN, Pfaller MA, Houston AK, et al. Removal of nosocomial pathogens from the contaminated glove: implications for glove reuse and handwashing. Ann Intern Med 1988;109:394-8.

4. Weiss SH, Goedert JJ, Gartner S, et al. Risk of human immunodeficiency virus (HIV-1) infection among laboratory workers. Science 1988;239:68-71.

5. Kotilainen HR, Brinker JP, Avato JL, et al. Latex and vinyl examination gloves. Quality control procedures and implications for health care workers. Arch Intern Med 1989; 149:2749-53.

6. Olsen RJ, Lynch P, Coyle MB, et a. Examination gloves as barriers to hand contamination in clinical practice. JAMA 1993;270:350-3.

Correspondence to: Vinay Prasad, v-prasad@md.northwestern.edu

Affiliation: Vinay Prasad is with the Department of Medicine, Northwestern University, Chicago, Ill.

CMAJ 2012. DOI:10.1503/cmaj.120953

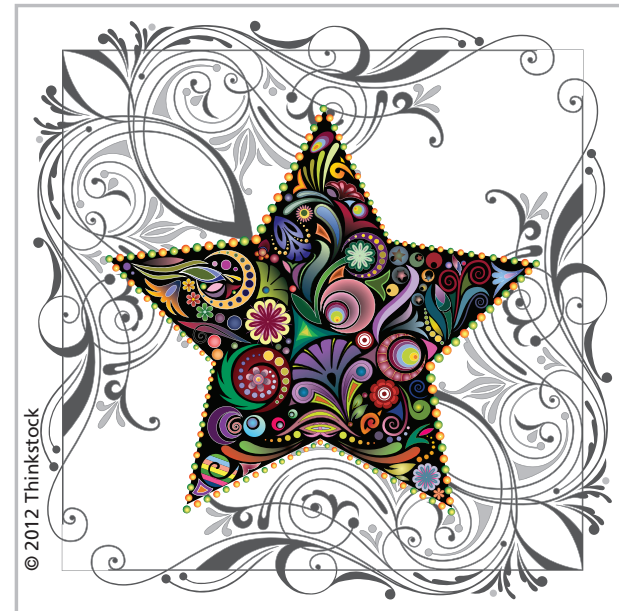

\section{Holiday reading acknowledgements}

CMAJ's call for entertaining Holiday Reading fare generated a recordbreaking number of submissions, prompting some spirited judging. Thank you to our esteemed panel of judges, Kate Brown, Kelly Clarke, Sarah Currie, Erin Driscoll, Wayne Kondro and Erin Russell, as well as to our talented designer Carole Lalonde. And a special thank you to everyone who submitted articles, poems and other holiday missives.

We hope our collective efforts bring you an hour or so of good reading over the holidays. - Barbara Sibbald, Deputy Editor, Analysis and Humanities, CMAJ

CMAJ 2012. DOI:10.1503/cmaj.121877 